\title{
Ecotoxicological evaluation of leachate from the Limeira sanitary landfill with a view to identifying acute toxicity
}

(doi:10.4136/ambi-agua.31)

\author{
Núbia Natália de Brito-Pelegrini ${ }^{1}$; Ronaldo Teixeira Pelegrini ${ }^{2}$; \\ José Euclides Stipp Paterniani ${ }^{1}$ \\ ${ }^{1}$ Universidade Estadual de Campinas, Faculdade de Engenharia Agrícola - UNICAMP - FEAGRI \\ E-mail: núbia.brito@agr.unicamp.br; pater@agr.unicamp.br \\ ${ }^{2}$ Centro Superior de Educação Tecnológica - CESET - UNICAMP \\ E-mail: pelegrini@ceset.unicamp.br
}

\begin{abstract}
Final disposal of solid waste is still a cause for serious impacts on the environment. In sanitary landfills, waste undergoes physical, chemical, and biological decomposition, generating biogas and leachate. Leachate is a highly toxic liquid with a very high pollution potential. The purpose of this work is to evaluate toxicity of in natura leachate samples collected from Limeira Sanitary Landfill, in Limeira, SP. The ecotoxicological evaluation comprised acute toxicity assays using as test organisms Daphnia Similis, seeds of Eruca sativa (arugula), and Allium cepa roots (onion). Analyses of color, $\mathrm{pH}$, turbidity, conductivity, hardness, nitrogen, total organic carbon (TOC), adsorbable organic halogen (AOX), and metals were also carried out. The main results for Eruca sativa (arugula) and Allium cepa (onion) indicated that the diluted leachate $50 \%$ presented similar toxicity to the phenol solution of $1000 \mathrm{mg} . \mathrm{L}^{-1}$ for arugula and $2000 \mathrm{mg} . \mathrm{L}^{-1}$ for onion. With the solution of $\mathrm{Cr}^{+6}$ concentrations of $3000 \mathrm{mg} . \mathrm{L}^{-1}$ for arugula and $2000 \mathrm{mg} . \mathrm{L}^{-1}$ for onion were found. For analyses with Daphnia Similis the EC50 was 9.3\% on average. This way it was possible to observe that biological tests are necessary to evaluate the pollution in the effluents or water bodies. These tests serve to determine the toxic potential of a chemical agent or complex mixture.
\end{abstract}

Keywords: acute toxicity; waste leachate; toxicity evaluation; sanitary landfill.

\section{Avaliação ecotoxicológica do percolado do aterro sanitário de Limeira visando à identificação da toxicidade aguda}

\section{RESUMO}

A disposição final de resíduos sólidos é uma prática que ainda traz sérios impactos ao meio ambiente. Nos aterros sanitários, os resíduos passam por processos físicos, químicos e biológicos de decomposição, gerando biogás e percolado. O percolado é um liquido com elevado potencial poluente e alta toxicidade. Este trabalho tem como objetivo o estudo da avaliação da toxicidade realizada em amostras de percolado ("in natura”) coletadas no Aterro Sanitário de Limeira-SP. A avaliação ecotoxicológica foi realizada através de testes de toxicidade aguda utilizando como organismos testes: Daphnia Similis, sementes de Eruca sativa (rúcula) e Allium cepa (cebola). Foram realizados também análises de Cor, pH Turbidez, Condutividade, Dureza, Nitrogênio, Carbono Orgânico Total (TOC), Halogênios Organicamente ligados (AOX) e Metais. Os principais resultados para Eruca sativa (rúcula) e 
Allium cepa (cebola) indicaram que o percolado diluído 50\% apresentou toxicidade similar a solução de fenol de $1000 \mathrm{mg} . \mathrm{L}^{-1}$ para rucúla e $2000 \mathrm{mg} . \mathrm{L}^{-1}$ para cebola. Com a solução de $\mathrm{Cr}^{+6}$ as concentrações encontradas foram de $3000 \mathrm{mg} . \mathrm{L}^{-1}$ para rúcula e $2000 \mathrm{mg} . \mathrm{L}^{-1}$ para cebola. Para as análises com Daphnias similis o CE50 foi, em média, de 9.3\%. Dessa forma foi possível observar que para avaliação da poluição dos efluentes ou corpos hídricos é necessário a utilização de testes biológicos por meio dos quais se determina o potencial tóxico de um agente químico ou de um mistura complexa.

Palavras-Chave: toxicidade aguda; percolado de aterro; avaliação da toxicidade; aterro sanitário.

\section{INTRODUCTION}

The final disposition of solids waste is a practice that still brings serious impacts to the environment, generating polluting byproducts such as leachate, a dark-colored, strongsmelling, highly toxic liquid. Leachate originates from the decomposition of organic matter, the intensity of pluvial waters, and other liquids derived from waste (Bertazzoli; Pelegrini 2002).

The toxicity and impact provoked for the Leachate on microflora and microfauna is very strong and they are influenced by various factors such organic matter, heavy metals and nitrogen concentrations, as well as mass flux of contaminants being transported (Isidori et al., 2003). Identifying compounds that cause the toxicity in the leachate is not easy because the physical-chemical characteristic of leachate is highly variable and dependant on the following factors: local environment conditions, time elapsed after waste disposal and landfill characteristics as well (Bertazzoli; Pelegrini 2002; Jeong-Hoon et al., 2001; Seco et al., 2003).

Toxicity tests are bioassays used in pollution control for determining the maximum permitted concentrations of a given chemical agent for the development/survival of certain living organisms (Buratini et al., 2004; Bertolleti et al., 1988; Zagatto et al., 1987). To measure the various effects of pollutants, it is important that toxicity tests are performed using organisms from different trophic levels (Bernard et al., 1997).

Toxic compounds can have two different effects on living organisms: acute toxicity, which is possible to evaluate in the short term upon the death of the organism, and chronic toxicity, whose evaluation takes longer since, in this case, sub-lethal effects must be analyzed (Buratini et al., 2004; Bertolleti et al., 1988; Zagatto et al., 1987).

In this work, acute toxicity was studied in samples of in natura leachate with a view to determining the degree of pollution and contamination of this wastewater.

\section{MATERIALS AND METHODS}

\subsection{Collection Site and Collection Methods}

Leachate was collected at the Limeira Sanitary Landfill, which is located on Tatuibi Road in Limeira, SP. The landfill comprises an area of approximately 50 hectares $(123,55$ acres) of which $190.000 \mathrm{~m}^{2}\left(2.045 .142,98 \mathrm{ft}^{2}\right)$ are meant for the disposal of domestic waste and industrial waste.

This landfill has a system for leachate drainage, which is treated in waste stabilization ponds. These leachate is first treated in an anaerobic pond and then in a facultative pond. Leachate was collected in polyethylene containers, which were stored in a dark room at approximately $4^{\circ} \mathrm{C}$ until sample analysis. This work was carried out from April to June 2005. 


\subsection{Implementation of applied methodologies}

\subsubsection{Determination of acute toxicity in Eruca sativa (arugula)}

A method still under study was used for the toxicological study with seeds of Eruca sativa (arugula). The method consists of placing a paper disk treated with the sample material in a Petri dish and then spreading 50 seeds of arugula on the disk surface. The purpose of the study is to determine the rate of germination of the arugula seeds as well as observe growth inhibition caused by the different concentrations of the sample within a 24- hour period.

\subsubsection{Determination of acute toxicity in Allium cepa (onion)}

A test using Allium cepa as a pattern for environmental monitoring was developed and presented by Fiskesjo (1985). In the case of leachate, the toxicological assays were performed using the method for industrial effluents proposed by Ribeiro (1999). The method consists on the disposal small onions at the chemistry tubes containing the sample in such a way that the onions' radicular systems (roots) are kept in contact with the sample. The purpose of the study is to determine the roots' rate of growth, as well as growth inhibition caused by different concentrations of the sample, all in a five-day period. The onions were kept at room temperature and under natural luminosity. Distilled water was used for both sample dilution and control, with onion bulb diameters ranging from 3.5 to $4.0 \mathrm{~cm}$.

\subsubsection{Determination of acute toxicity in Daphnia similis}

The method specified under NBR 12713 (ABNT, 2003) was used in the toxicological assay with Daphnia similis. It consists of exposing young organisms of the genus Daphnia to various dilutions of the sample within a period of 48 hours.

\subsection{Analyses}

The following parameters were employed to evaluate toxicity of leachate: $\mathrm{pH}$, color, turbidity, conductivity, hardness, nitrogen, total organic carbon (TOC), adsorbable organic halogen (AOX), and metals.

All analyses were performed in accordance with the Standard Methods for the Examination of Water and Wastewater 20th Edition (1998), except for the analysis of TOC, which was in accordance to ISO 8245 (ISO, 1999), and the analysis AOX, which was carried out according to the methodology specified under ISO 9562 (ISO, 1989), using a TOC Euro Glass 1200 device.

\section{RESULTS AND DISCUSSION}

\subsection{Leachate Toxicity}

The studies were aimed to estimate the rate of inhibition of seed germination for arugula and onion (Figure 1) and Daphnias similis (Figures 2 and 3).

In order to estimate leachate toxicity, studies were carried out using solutions of phenol and $\mathrm{Cr}^{+6}$ at an inhibition rate similar to that found in leachate diluted to the $50 \%$ strength. The results indicated similar toxicity to that found for the phenol solution to $1000 \mathrm{mg} . \mathrm{L}^{-1}$ used for arugula and $2000 \mathrm{mg} . \mathrm{L}^{-1}$ for onion. For $\mathrm{Cr}^{+6}$, the concentrations found were $3000 \mathrm{mg} . \mathrm{L}^{-1}$ for arugula and 2000 mg. $\mathrm{L}^{-1}$ for onion (Figure 1 ).

In the case of Daphnias similis, various preliminary tests were also carried out and a specific computer program (Jsper) for the calculation of the EC50 was used (Figures 2 and 3). 
It was possible to observe that the concentration that inhibited $50 \%$ of the organisms in this case was practically the same for all the assays performed during the three months of research.

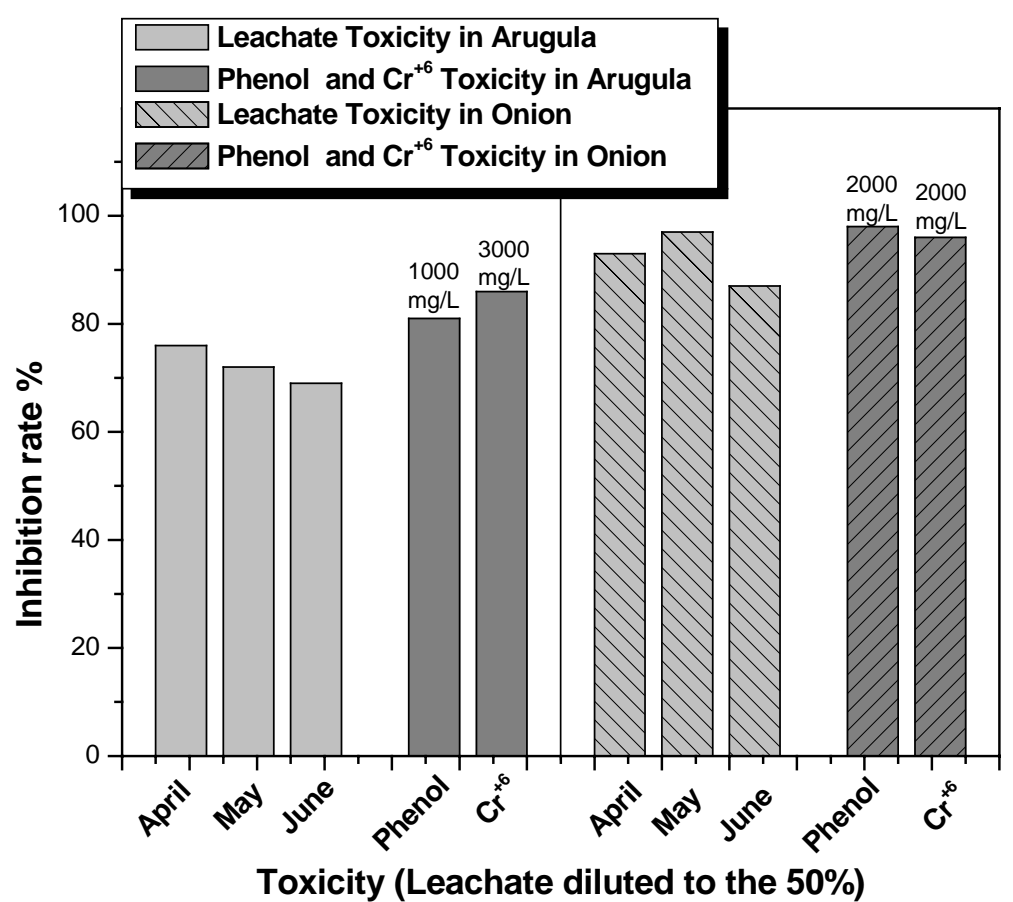

Figure 1. Toxicity assay for arugula and onion, leachate diluted to $50 \%$ strength, as compared to solutions of phenol and $\mathrm{Cr}^{+6}$ (April-June 2005).

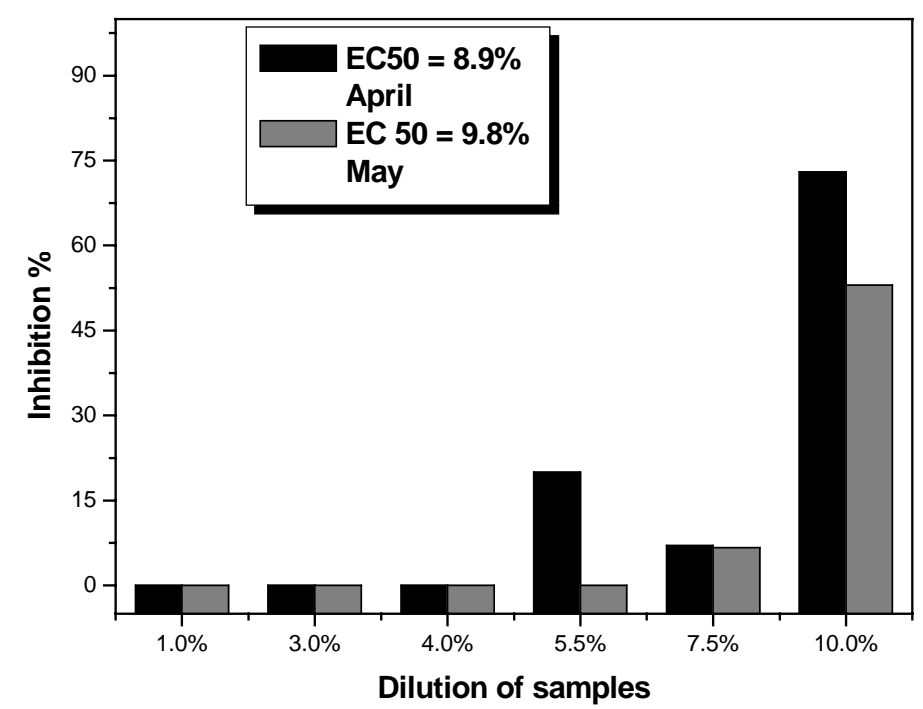

Figure 2. Assay using Daphnia similis- April-May 2005. 


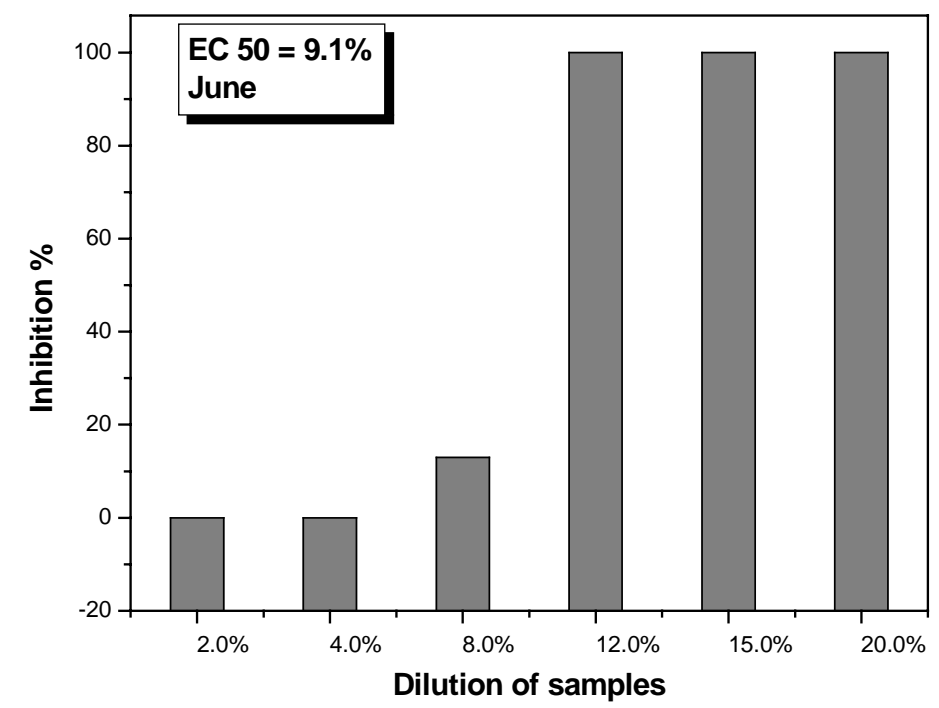

Figure 3. Assay using Daphnia similis- June 2005.

The results of the toxicity assays highlight the high pollution potential of landfill leachate in the city of Limeira. The impacts caused by this type of matrix are usually due to synergetic interaction between the various pollutants. High concentrations of heavy metals, organic matter, nitrogen, and organo-halogenated substances are known to contribute to extreme elevation of toxicity levels in any environment. These classes of compounds are a risk to the ecosystems and public health.

\subsubsection{Metals found in the leachate}

In the leachate samples studied, it was possible to detect the presence of various metals deemed as hazardous to the ecosystems (Table 1). The action of metals within the intracellular compartments can be verified in various manners. A few species are bonded to extra-cellular proteins, others are adsorbed at the level of cell walls, and yet others are diffused through the cell membrane (Araujo et al., 2006).

Table 1. Metal counts readings.

\begin{tabular}{c|c|c|c|c|c|c|c|c|c|c|c}
\hline Metals & Al & Cd & Pb & Cu & Cr & Ni & Zn & K & Na & Fe & Mn \\
\hline $\begin{array}{c}\text { Concentration } \\
\text { mg.L. }^{-1}\end{array}$ & 25.20 & 2.15 & 1.62 & 39.0 & 5.01 & 11.4 & 33.5 & 6.23 & 1825.00 & 54.16 & 17.48 \\
\hline
\end{tabular}

Cadmium, which was found in leachate at levels considerably above the standards for effluent disposal (0.2 mg. $\mathrm{L}^{-1}$ ) (Brasil, 2005) has both a toxic and mutagenic effect on the aquatic biota. The effects on algae and invertebrates are related to an increase in cell volume and inhibition of the flow of calcium. The effects on fishes include inhibition of the various enzyme systems, such as those involved in neurotransmission, trans-epithelial transport, intermediate metabolism, and antioxidant activities. Long-term exposure to non-lethal concentrations has been reported to be connected with skeletal deformations. In the case of vertebrates, the effects are usually related to hypocalcaemia, which results from inhibition of the flow of calcium (Araujo et al., 2006). 
Copper, despite being a micronutrient for both plants and animals, is known to be toxic to the aquatic biota when at high concentrations (maximum permitted level $=1.0 \mathrm{mg} . \mathrm{L}^{-1}$ ) (Brasil, 2005). Although little is known about the primary mechanism of toxicity in plants, it is possible to say that its main effects are photosynthesis inhibition and rupture in vegetative growth (Araujo et al., 2006).

Chrome is known to be a very toxic element, especially in high oxidation number. In leachate, chrome was detected at concentrations 100 times higher than those permitted under disposal standards (Wang et al., 2005).

Lead is potentially carcinogenic and its toxic effects on humans can be detected via symptoms originated in the nervous system, such as muscle tremor, convulsions, paralysis, and coma (Wang et al., 2005).

Nickel and zinc were also found in large amounts, and other metals commonly found in water, such as iron and manganese, were also detected in leachate at concentrations often times exceeding the permitted disposal standards (Wang et al., 2005).

All bivalent metals are known to quickly react with proteins from the amino, imino, and sulphidric groups, and a few of these metals compete with essential elements such as zinc, by dislodging from their binding sites (Araujo et al., 2006; Zoumis et al., 2000; Hirchmann; Forstner, 2000).

Mobilization of heavy metals from the landfill into leachate usually occurs both when hydrated ions are formed and by complexation with organic substrates with low molecular weight (amino acids and sugars), with polymers (fulvic and humic acids), and with colloids of high molecular weight (Zoumis et al., 2000; Hirchmann; Forstner, 2000). These organic compounds are highly colored and high coloration is one way to quantify them, as well as studying color intensity.

A study of leachate coloration was conducted with absorbance rates measured at a $400 \mathrm{~nm}$ wavelength (Table 2). Absorbance rates of 2.46 on average were verified during the study, indicating high concentrations of organic materials capable of complexation with heavy metals. It is also important to stress that high coloration of effluents can strongly interfere with the photosynthetic processes thereby causing alterations in the aquatic biota (Kapdan et al., 2000; Kirby et al., 2000).

Significant amounts of heavy metals can also bond to both inorganic and organic particulate matter, both of which constitute an important means for leachate transportation. Turbidity measurements can also provide an estimate of the amount of particulate matter contained in leachate (Table 2). The specific area of suspended material is large and in the case of leachate, the particles can accommodate large amounts of pollutants. It was possible to observe high turbidity, which was representative of high concentrations of particulate matter. This result can indicate an increased transposition of pollutants into the leachate in addition to the resistance that the excess suspended material opposes to the passage of light. 
Table 2. Average values of the parameters analyzed.

\begin{tabular}{l|c|c}
\hline \multicolumn{1}{c|}{ Parameters } & Mean Values & SD \\
\hline $\mathrm{pH}$ & 8.01 & 0.20 \\
\hline $\begin{array}{l}\text { Color - Abs. } \\
(400 \mathrm{~nm})\end{array}$ & 2.46 & 0.39 \\
\hline $\begin{array}{l}\text { Turbidity } \\
(\mathrm{UT})\end{array}$ & 68.70 & 48.83 \\
\hline $\begin{array}{l}\text { Condutivity } \\
(\mathrm{mS})\end{array}$ & 12.21 & 0.65 \\
\hline $\left.\begin{array}{l}\text { Hardness } \\
\left(\mathrm{mg} . \mathrm{L}^{-1} \mathrm{CaCO}\right.\end{array}\right)$ & 934.00 & 448.50 \\
\hline TOC (mg.L $\left.{ }^{-1}\right)$ & 1116.10 & 550.77 \\
\hline $\begin{array}{l}\mathrm{AOX} \\
\left(\mu g . \mathrm{L}^{-1}\right)\end{array}$ & 690.70 & 370.95 \\
\hline $\mathrm{NH}_{4}{ }^{+}\left(\mathrm{mg} . \mathrm{L}^{-1}\right)$ & 426.00 & 13.65 \\
\hline
\end{tabular}

SD- Standard Deviation.

\subsubsection{Organic Compounds in leachate}

Leachate is a matrix with a high degree of variation in the contents of TOC. That is due to the fact that, in leachate, high concentrations of degrading materials are continuously undergoing consecutive dilutions by both rainwater and recirculation of leachate itself. It was observed TOC values that were higher than 1000.00 mg.L ${ }^{-1}$, which characterizes wastewater with a high content of organic matter (Table 2).

In landfills over 10 years of age but still in operation, as it is the case, it is possible to find a countless number of organic compounds present in leachate which are derived from both short-term and medium-term decomposition as well as non-biodegradabable substances, the latter accounting for the strongest impact on the environment.

The structure of organic compounds is a determining factor in toxicity analyses. Organonitrogenated substances for instance have a highly polluting potential, especially due to its metabolites, among which is ammonia. High concentrations of ammoniacal nitrogen were detected in leachate (Table 2). Concentrations exceeding $400.00 \mathrm{mg} . \mathrm{L}^{-1}$ could be observed throughout the monitoring period.

The organo-halogenated compounds determined in the AOX parameter analysis are commonly defined as the fraction corresponding to the concentration containing adsorbable organically bound halogens. This class of substances is represented by highly toxical and mutagenic chemical species such as the organochlorides, the halogenated agrochemicals, the CFCs, etc. In leachate, high concentrations of AOX were detected $(900 \mu \mathrm{g} / \mathrm{L})$, which can cause great concern since they can persist in the aquatic environments/habitats and cause bioaccumulation (Table 2).

\subsubsection{Toxicity and Bioavailability}

The effects of toxicity of organic compounds on the aquatic organisms can range from mortality to hepatoxicity, immunotoxicity, carcinogenicity, and metabolic alterations that can lead to a decrease in the rates of reproduction, predation, and decomposition (Araujo et al., 2006; Dave; Nilsson, 2005). 
Organo-halogenated and organo-nitrogenated compounds as well as heavy metals remain highly toxical, with a high potential of bioavailability, especially when they are water-soluble. The $\mathrm{pH}$ values and the ion exchange capacity are important factors that interfere with the relation between adsorption and deadsorption in compounds as it may render the specie either more or less available.

$\mathrm{pH}$ values of leachate were found to be slightly alkaline. This is due to the methanogenic phase of solid waste degradation at the landfill and can contribute to reduce toxicity levels since these alkaline values can favor the precipitation of metals by making them less bioavailable (Table 2).

The high values of conductivity were found for wastewaters and may influence the death of test organisms due to the excess concentration of salts and an increase in the ionic exchange ability of the compounds (Table 2). This fact is deemed unfavorable as it causes the toxicity of leachate to increase.

Water from the studied leachate is classified as hard water (carbonate concentration high) (Table 2). Studies have suggested that very hard water is capable of reducing toxicity of a few metals such as cadmium, copper, and lead. That occurs when this water complexes with these metals, thereby making them insoluble and causing bioaccumulation to decrease (Borgmann et al., 2005; Borgmann et al., 2004; Markich et al., 2005). In this case, hardness can be deemed to favor toxicity reduction.

\section{CONCLUSIONS}

This work corroborates the high toxicity indexes found in the leachate samples studied. Ecotoxicological evaluation of wastewater from such a source is fundamental for assessing the risks posed to both the environment and public health in municipalities where waste is not adequately treated.

Characterization of physico-chemical parameters of leachate such as $\mathrm{pH}$, turbidity, and conductivity, as well as chemical parameters such as hardness, TOC, AOX, and the presence of nitrogen, biological parameters such as toxicity, and potentially available metals such as $\mathrm{Cd}, \mathrm{Cu}, \mathrm{Cr}, \mathrm{Pb}, \mathrm{Zn}, \mathrm{Ni}, \mathrm{Fe}, \mathrm{Mn}$ were of fundamental importance in determining the contaminants present in this effluent and evaluating the potential impact of landfill leachate.

\section{ACKNOWLEDGMENTS}

The authors would like to acknowledge financial support from CNPq.

\section{REFERENCES}

ARAUJO, R. P. A.; BOTTA-PASCHOAL, C. M. R.; SILVERIO, P. F.; ALMEIDA, F. V.; RODRIGUESS, P. E.; UMBEZEIRO, G. A. et al. Application of toxicity identification evaluation to sediment in a highly contaminated water reservoir in southeastern Brazil. Environmental Toxicology and Chemistry, Brussels, v. 25, n. 02, p. 581-588, 2006.

ASSOCIAÇÃO BRASILEIRA DE NORMAS TÉCNICAS. NBR 12713: Ecotoxicologia aquática: toxicidade aguda: método de ensaio com Daphnia spp (Cladocera, Crustacea). Rio de Janeiro: ABNT, 2003.

BERNARD, C.; COLIN, J. R.; ANNE, L. D. D. Estimation of the hazard of landfills through toxicity testing of leachates. Chemosphere, [S.l.], v. 35, n. 11, p. 2783-2796, 1997. 
BERTAZZOLI, R.; PELEGRINI, R. Photoeletrochemical discoloration and degradation of organic pollutants in aqueous solutions. Química Nova, São Paulo, v. 25, n. 03, p. 477482, 2002.

BERTOLLETI, E.; ARAÚJO, R. P. A.; ZAGATTO, P. A.; CHERARDIGOLDSTEIN, E. Toxicity evaluation of paper-mill effluents. Water Science and Technology, London, v. 20, n. 02, p. 191-198, 1988.

BORGMANN, U.; NORWOOD, W. P.; DIXON, D. G. Re-evaluation of metal bioaccumulation and chronic toxicity in Hyalella azteca using saturation curves and the biotic ligand model. Environmental Pollution v. 131, n. 03, p. 469-484, 2004.

BORGMANN, U.; COUILLARD, Y.; DOYLE, P.; DIXON D. G. Toxicity of sixty-three metals and metalloids to Hyalella azteca at two levels of water hardness. Environmental Toxicology and Chemistry, Brussels, v. 24, n. 03, p. 641-652, 2005.

BURATINI, S. V.; BERTOLLETI, E.; ZAGATTO, P. A. Evaluation of daphnia similis as a test species in ecotoxicological assays. Bulletin of Environmental Contamination and Toxicology, v. 73, n. 05, p. 878-882, 2004.

BRASIL. Ministério do Meio Ambiente. Conselho Nacional do Meio Ambiente. Resolução CONAMA 357. 2005. Disponível em: < http://www.mma.gov.br/port/conama>. Acesso em: 17 outubro 2007.

DAVE, G.; NILSSON, E. Increased reproductive toxicity of landfill leachate after degradation was caused by nitrite. Aquatic Toxicology v. 73, n. 01, p.11-30, 2005.

FISKESJO G. The Allium test as a standard in environmental monitoring. Hereditas, v. 102, p. 99-112, 1985.

HIRCHMANN, G.; FORSTNER, U. Long-term assessment for the leachate release of heavy metals from municipal solid waste incineration bottom ash monofills. Acta Hydrochimica Hydrobiologica, v. 28, n. 05, p. 262-271, 2000.

INTERNATIONAL STANDARD ORGANIZATION. ISO 9562: water quality: determination of adsorbable organic halogens (AOX). Geneva: ISO, 1989.

INTERNATIONAL STANDARD ORGANIZATION. ISO 8245: guidelines for the determination of total organic carbon (TOC) and dissolved organic carbon (DOC). Geneva: ISO, 1999.

ISIDORI, M.; LAVORGNA, M.; NARDELLI, A.; PARELLA, A. Toxicity identification evaluation of leachates from municipal solid waste landfills: a multispecies approach. Chemosphere, v. 52, n. 01, p. 85-94, 2003.

JEONG-HOON, I.M.; HAE-JIN, W.; MYUNG-WON, C.; KI-BACK, H.; CHANG-WON, K. Simultaneous organic and nitrogen removal from municipal landfill leachate using an anaerobic-aerobic system. Water Research, v. 35, n. 10, p. 2043-2410, 2001.

KAPDAN, I. K.; KARGI, F.; MCMULLAN, G.; MARCHANT, R. Biological decolorization of textile dyestuff by Coriolus versicolor in a packed column reactor. Environmental Technology, v. 21, n. 02, p. 231-236, 2000. 
KIRBY, N.; MARCHANT, R.; MSMULLAN, G. Decolourisation of synthetic textile dyes by Phlebia tremellosa. Fems Microbiology Letters, v. 188, n. 01, p. 93-96, 2000.

MARKICH, S. J.; BATLEY, G. E.; STAUBER, J. L.; ROGERS, N. J.; APTE, S. C.; HYNE, R.V. et al. Hardness corrections for copper are inappropriate for protecting sensitive freshwater biota. Chemosphere v. 60, n. 01, p. 1-8, 2005.

RIBEIRO, I. A. Teste de raízes de cebola para avaliação de toxicidade de efluentes industriais. Engenharia Sanitária Ambiental, v. 4, n. 03, p. 108-112, 1999.

SECO, J. I.; FERNÁNDEZ-PEREIRA, C.; VALE, J. A study of the leachate toxicity of metal-containing solid wastes using Daphnia magna. Ecotoxicological Environmental Safety, v. 56, n. 03, p. 339-350, 2003.

ZAGATTO, P. A.; CHERARDIGOLDSTEIN, E.; BERTOLLETI, E.; LOMBARDI. C.C.; MARTINS, M. H. R. B.; RAMOS, M. L. L. C. Bioassays with aquatic organismstoxicity of water in sediment from Cubatão river basin. Water Science and Technology, London, v. 19, n. 11, p. 95-106, 1987.

ZOUMIS, T.; CALMANO, W.; FORSTNER, U. Demobilization of heavy metals from mine waters. Acta Hydrochimica Hydrobiologica, v. 28, n. 04, p. 212-218, 2000.

WANG, X.; SATO T.; BAOSHAN, X.; TAO, S. Health risks of heavy metals to the general public in Tianjin, China via consumption of vegetables and fish. Science Total Environmental, v. 350, p. 28-37, 2005. 